\title{
Compensation for Drug Injury
}

\section{Product liability all dressed up American style}

\author{
RICHARD SMITH
}

In $1957 \mathrm{Mr}$ Greenman, an American, was working with a Shopsmith, a tool that could be used as a saw, a drill, and a lathe, when a piece of the wood he was working on flew out and injured him. About a year later he brought an action against the retailer, and the manufacturer, Yuba Products Inc. $\mathrm{He}$ claimed breach of both "implied" and "express" warranty and negligence. Express warranty is when a seller makes a specific promise about his products, such as "This drug has no known side effects." Implied warranty is a warranty which the law reads into every sale whereby a seller represents that his products are of merchantable quality and reasonably fit for their purpose. Mr Greenman's case against the retailer was not upheld, but the jury found against the manufacturer and awarded $\$ 65000$ damages. Both Mr Greenman and the manufacturer appealed. The Californian Supreme Court in 1963 upheld the lower court's decision. Justice Traynor wrote in his judgment:

"A manufacturer is strictly liable when an article he places on the market, knowing that it is to be used without inspection for defects, proves to have a defect that causes an injury to a human being.... The purpose (of imposing strict liability on manufacturers) is to insure that the costs of injuries resulting from defective products are borne by the manufacturers that put such products on the market rather than by the injured persons who are powerless to protect themselves. ... To establish the manufacturer's liability it was sufficient that the plaintiff proved that he was injured while using the Shopsmith in a way it was intended to be used as a result of a defect in design and manufacture of which the plaintiff was not aware that made the Shopsmith unsafe for its intended use."1

A plaintiff had to prove only that he was injured because of a defect in a product: he had no need to prove negligence on the part of the manufacturer. Thus strict liability in tort for productinduced injury appeared in the United States.

\section{Restatement of Torts}

In 1965 the American Law Institute drafted the Restatement (Second) of the Law of Torts. Stimulated by the Greenman case it included the principle of strict liability for productinduced injury in Section 402A, which states:

(1) One who sells any product in a defective condition unreasonably dangerous to the user or consumer or to his property is subject to liability for physical harm thereby caused to the ultimate user or consumer, or to his property, if:

British Medical Journal, London WC1H 9JR

RICHARD SMITH, BSC, MB, assistant editor (a) the seller is engaged in the business of selling such a product, and

(b) it is expected to and does reach the user or consumer without substantial change in the condition in which it is sold.

(2) The rule stated in Subsection (1) applies although:

(a) the seller has exercised all possible care in the preparation and sale of his product, and

(b) the user or consumer has not bought the product from or entered into any contractional relation with the seller.

Two comments on the section are particularly relevant to prescription drugs.

Where, however, the product contains an ingredient to which a substantial number of the population are allergic ... the seller is required to give warning against it, if he has knowledge, or by the application of reasonable, developed human skill and foresight should have knowledge, of the presence of the ingredient and its danger. . . . Where warning is given, the seller may reasonably assume that it will be read and heeded; and a product bearing such a warning, which is safe for use if it is followed, is not in defective condition, nor is it unreasonably dangerous.

There are some products which, in the present state of human knowledge, are quite incapable of being made safe for their intended and ordinary use. These are especially common in the field of drugs.... Such a product, properly prepared, and accompanied by proper directions and warning, is not defective, nor is it unreasonably dangerous.

Thus a manufacturer was liable for all injuries resulting from drugs not made to the design specifications even if he had taken as much care as possible. He was not, however, strictly liable in most cases when the drug was made exactly to design specifications yet still injured the patient. Only if he had failed to warn of a side effect that he should have known about was he liable, and this effectively was the same as negligence. Similarly, the manufacturer needed to warn only of side effects that were foreseeable in a "substantial number" of users. Some courts-particularly in California-have now begun, however, to move beyond the Restatement and find manufacturers liable in cases where the design of a drug was defective. The complexities of the law may be illustrated by considering a few cases.

\section{Claims against manufacturers}

If a drug is not manufactured to the design specification and it injures somebody the manufacturer will be liable under negligence, breach of implied warranty, and strict liability. Most manufacturers are willing to accept this kind of liability, and it presents few legal problems.

Design defect, when a drug is developed, then tested as fully as possible, manufactured to specification, yet injures people 
after being put on to the market, is the crucial issue in product liability. Drug manufacturers are usually willing to accept liability for production defects and failure to warn, but they balk at liability without fault for design defects. Lawyers and consumers also think that design defects are the most important, and after thalidomide, practolol, and now diethylstilboestrol (DES) this is where they have concentrated their reforming energy.

The Debendox case, which has received much publicity, is an example of a case over an alleged design fault. Debendox (sold as Bendectin in the United States) is an antinausea drug manufactured by Richardson-Merrell for use in pregnancy. It has been sold in the United States for 23 years, and an estimated 30 million pregnant women throughout the world have taken the drug. In the last two years, however, some people have suggested that the drug may cause congenital malformations. Many lawsuits have resulted, and although a panel of the Food and Drug Administration has agreed unanimously² that there is no demonstrated association between Bendectin and birth defects, these suits continue.

The first case to come to court was that brought by Michael and Elizabeth Mekdeci in Florida in 1980. They alleged that their son David was injured by the drug, and they sued RichardsonMerrell for $\$ 12 \mathrm{~m}$. The court's decision was a peculiar one, and was interpreted by both sides as a victory. The jury decided that nothing should be awarded to the boy and no damages should go to the parents, but the parents should receive $\$ 20000$ for medical expenses. A Federal judge overturned this decision on the grounds that it was inconsistent: if the jury thought the drug caused the injuries they should have awarded damages, if they did not think it did they should not have awarded anything. The case was retried, and the jury agreed unanimously that the drug had not caused the injuries. Although the original decision was clearly illogical, it is easy to imagine the jury's thinking: they were unconvinced by the evidence, but they thought that a rich drug company would not miss $\$ 20000$, which would help the boy and his parents enormously.

\section{Diethylstilboestrol: America's thalidomide?}

The DES cases are the most recent and most interesting drug liability cases in the United States. They have excited some lawyers, who see the legal changes made by the cases as revolutionary, and they have worried the drug companies.

Stilboestrol was first synthesised in 1937 in Britain. It was the first synthetic, non-steroidal, oestrogen-like substance, could be taken orally, and cost about $1 / 300$ th of the cost of natural oestrogens. A patent was not applied for. A dozen drug companies in the United States tested the drug and applied to the Food and Drug Administration for a licence to market the drug for a variety of uses-none of which concerned pregnancy. Licences were granted in the autumn of 1941. At that time a drug application would usually contain reports on about $150-300$ patients. Applications to market DES included reports on more than 5000 patients, none of whom were pregnant. Doctors knew, however, that high doses of any oestrogen could cause cancer in rats, and the warnings of some companies suggested that the drug should be avoided in patients with cancerous or precancerous lesions of the breast or cervix.

In 1947 the FDA began to give permission for the drug to be used in treating women with problem pregnancies, particularly those who had early miscarriages. In 1952 the FDA allowed any company to market DES without needing to make a further application. By 1953148 companies were manufacturing the drug, and since then about 300 companies have marketed it; about a third of those companies no longer exist. DES gained its peak use in problem pregnancies in the early ' $50 \mathrm{~s}$, but its use had fallen sharply by 1960 , when progesteronc became available. The drug is estimated to have been used in about 1 million pregnancies in America.

In $1971 \mathrm{Dr}$ Arthur Herbst and others reported a statistical association between mothers being given DES in pregnancy and their daughters subsequently developing clear cell adenocarcinoma of the vagina and cervix. ${ }^{3}$ Dr Herbst set up a worldwide register of this cancer in young women. He reported in 1979 on the 284 cases he had collected. ${ }^{4}$ About two-thirds of these women gave a history of their mother taking DES during pregnancy. The cancer is linked with the drug, but as Herbst has said: "We have clearly stated that the occurrence of these cancers is not due to DES alone." Also about $90 \%$ of the "DES daughters" had adenosis of the vagina and they were more likely to have had miscarriages. There may be an increased incidence of genitourinary abnormalities in male offspring, and it is anybody's guess what the effects might be as the sons and daughters get older.

The first case against a manufacturer was brought in 1971, and there are now more than 500 lawyers concerned in DES suits. One typical case is that of Joyce Bichler. In 1953 Dorothy Bichler, Joyce's mother, was given a prescription for DES for vaginal bleeding while pregnant. Nobody knows who made the drug she was prescribed. The doctor prescribed the drug because he had read about it in a medical journal and knew "gynaecologists all over the world" were using it.

Joyce Bichler was born normal and healthy in January 1954, but in 1971 she had cancer diagnosed and underwent hysterectomy and vaginectomy. In October 1974 she and her father brought an action against Eli Lilly and Company, the BronxLebanon Hospital Centre, and the doctor. In March 1975 they also sued the chemist who had sold Dorothy Bichler the drug, but this suit was dismissed in May 1978. The case against the hospital was dismissed in April 1977.

In 1979 the court set a date for the remaining trials, ordered that there should be a separate trial on whether Lilly made the drug that Dorothy Bichler took, and also allowed that the plaintiff could maintain her case against Lilly even if she could not prove that the company had made the drug. The doctor settled out of court for $\$ 30000$, and the trials started in May 1979. The first jury decided that Lilly did not make the drug. In a second trial the jury found Lilly liable and awarded $\$ 500000$ damages. The trial ended on 16 July 1979, and Lilly are now appealing.

The decision is remarkable in several ways. It seems to fly in the face of the law written down in the Restatement (Second) of Torts. Drugs are products which are regarded as "unavoidably unsafe" and a manufacturer is not liable for every injury. The manufacturer is required to give a warning, however, "if he has knowledge, or by the application of reasonable, developed human skill and foresight should have knowledge, of the presence of the ingredient and the danger." Also, Eli Lilly were held liable even though it could not be proved that it had made the drug because it had acted "in concert with unidentified other drug companies" in the testing and marketing of DES.

In another DES case this year the Supreme Court of California decided that a woman, Judith Sindell, who claims to have been injured by DES (and does not know which company made the drug) can sue all the companies who have manufactured DES. The only precedent in tort law is a case in which a hunter was shot while out with two other hunters. The court then was sure that one of the two hunters was negligent but as it could not know which it found both liable. It does seem a big jump, however, from holding two people liable knowing that one was negligent to holding almost a whole industry liable. Indeed, there is an attempt in the Californian legislature to overturn the Supreme Court's decision.

Many lawyers see the Californian decision as a legal breakthrough: several women have suffered awful injuries and they should be compensated; the drug companies make money out of successful drugs, and they should be prepared to compensate for damages; the question of fault is irrelevant-it is simply a case that the drug companies are best able to pay. The drug companies, however, see this as an awful decision. The costs will be enormous, they argue; drug prices will rise steeply; competition and innovation will be reduced; companies will go bankrupt; and also companies will stop producing unpatented

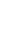


drugs. That would mean an end to generic prescribing, something that the Federal government is trying to introduce.

\section{Failure to warn}

American case law seems to dictate that a drug manufacturer cannot be liable for a side effect that he has warned a doctor about. Nor could the manufacturer (at least before the DES cases) be liable for not warning about unforeseeable side effects. Variations in State law and individual court decisions have made for inconsistencies, however, as in other product liability cases.

Richardson-Merrell marketed MER/29, a drug for lowering blood cholesterol concentrations, in April 1960 without any warnings of serious side effects. In mid-1961 the company produced a warning about possible hair loss and in December 1961 they added warnings about the possibility of eye damage. The company had, however, known about blindness in rats receiving high dosages since October 1960. The first human cases were reported in October 1961.

Some 5000 people were injured, but only 1500 filed suits, and of the five reported cases the plaintiff won in only two. $\mathrm{Mr}$ Toole took the drug from July 1960 until December 1961 and developed cataracts in both eyes. A Californian court in 1969 found for Mr Toole and awarded him $\$ 250000$ on the grounds of negligence in failing to adequately test the drug, failure to provide adequate warnings, fraud, and breach of express and implied warranty.

Mr Cudmore in Texas, however, got nothing for the same injuries. The court ruled that the manufacturer had no duty to warn unless "foreseeable" harm would result to "an appreciable number of persons." Mr Lewis in Oregon also got nothing and the court ruled that: "We held that upon such facts a drug, properly tested, labelled with appropriate warnings, approved by the Food and Drug Administration, and marketed under federal regulation, is as a matter of law, a reasonably safe product."

This raises another fundamental issue: does a Government licence mean that a drug has by definition been adequately tested ? The drug manufacturers think that they are caught in a double bind: they must spend a great deal of time and money to fulfil the FDA licensing criteria but in most States this gives them no legal protection if a serious side effect is subsequently discovered.

\section{Claims against prescribing doctors}

In the United States injured people who are seeking compensation will commonly sue everybody possible. If they think that they have a good case against a drug company they will concentrate their energies there. Doctors are not involved when there is a defect in the drug or in the manufacturer's warnings.
But claims are upheld against doctors in an inconsistent way for the following reasons: failing to follow the manufacturer's labelling; ignoring contraindications; ignoring warnings against method of use; ignoring recommended dosage; using the wrong drug; and failing to obtain informed consent.

Some of these forms of liability will not seem outrageous to British doctors, but I want to dwell a little on following the manufacturer's instructions and informed consent. Some British doctors are worried that if new product liability legislation is introduced they will have to follow manufacturers' instructions strictly to avoid litigation. But this is not the case in the litigious United States. The AMA has said: "Drug labelling may have evidentiary weight for or against a physician, but the evidence is subject to refutation; drug labelling, per se, does not set the standard for what is good medical practice." Another worry of some British doctors is that they will be obliged to tell patients of every conceivable side effect to avoid litigation. Again, this is not the case in the United States. The Americans do have a law of informed consent, but as George J Annas has written in the New England fournal of Medicine:

Perhaps the legal profession has been derelict in its exposition of the doctrine of informed consent, but it strikes me as almost incomprehensible that any physician would believe he had to "persist with a potentially frightening dissertation for 'legal reasons" " in the face of a patient who protests that he does not want to hear it. This situation, of course, would be easily understood without reference to legal authority by anyone who understood the primary purposes of the informed-consent doctrine; to protect the patient's right of self-determination, and to promote rational decision making. The first means that a patient's expressed desire not to be told about risks should be honoured and the second that if the physician can document that risk disclosure will make the patient too ill or emotionally distraught as to foreclose a rational decision, no such disclosure need be made. $^{5}$

Even in the United States a doctor is not legally required to tell his patient everything.

This is the second of three articles.

\section{References}

1 Greenman $v$ Yuba Power Products Inc. (377 P2d 897), USA, 1963.

2 Kolata GB. How safe is Bendectin ? Science 1980 ;210:518-9.

${ }^{3}$ Herbst AL, Ulfelder $H$, Poskanzer DC. Adenocarcinoma of the vagina: association of maternal stilestrol therapy with tumor appearance in young women. $N$ Engl f Med 1971 ;284:878-81.

4 Herbst AL, Scully KE, Robboy SJ. Prenatal diethylstilbestrol exposure and human genital tract abnormalities. Natl Cancer Inst Monogr 1979; $\mathbf{5 1}: 25-35$

5 Annas GJ. Legal aspects of informed consent. N Engl F Med 1977;297:228.
What is accepted as the best regimen for controlling female idiopathic senile osteoporosis?

Normal women begin to lose bone at appreciable rates after the menopause. Prospective studies show that in most women bone loss may be halted with oestrogen replacement therapy. Supplementary calcium has a somewhat lesser effect in younger patients, but in people over 65 malabsorption of calcium is common and may be partially corrected with large calcium supplements (1-2 g elemental calcium a day-for example, as Sandocal containing $0.4 \mathrm{~g}$ per tablet or as the carbonate or lactate). Neither oestrogens nor calcium supplements have been shown to reverse the loss of bone with age, so a patient who has already sustained fractures remains at risk of further fractures. The mineral retained as a result of oestrogens is also lost fairly rapidly after treatment is stopped, so to be effective treatment must be prolonged; even so, small doses are effective ${ }^{1}$ - for example, 5-10 $\mu \mathrm{g}$ of ethinyl oestradiol daily three weeks out of four. For the reversal of established trabecular bone loss three regimens have been advocated: the combination of sodium fluoride and calcium supplements; alternating phosphate supplements and calcitonin injections ${ }^{2}$; and injections of a fragment of human parathyroid hormone. ${ }^{3}$ None are effective (as judged histologically) in all patients, the first regimen is associated with a high incidence of side effects, and several practical questions need to be answered by further clinical trials before any of them can be recommended for routine use. ${ }^{4}$

\footnotetext{
1 Anonymous. Treatment of osteoporosis. $\mathrm{Br}$ Med $\mathcal{F} 1978$; i :1303-4 政 and calcitonin on bone volume in osteoporosis. Metabolic Bone Disease and Research 1980;2:107-11.

eve J, Meunier PJ, Parsons JA, et al. Anabolic effect of human parathyroid hormone fragment on trabecular bone in osteoporosis: a multicentre trial. Br Med F 1980;280:1340-52.

Baylink DJ, Ivey JL. Sodium fluoride for osteoporosis-some unanswered questions. F $A M A$ 1980;243:463-4.
} 